This item was submitted to Loughborough's Research Repository by the author.

Items in Figshare are protected by copyright, with all rights reserved, unless otherwise indicated.

\title{
Thermal depoling of high Curie point Aurivillius phase ferroelectric ceramics
}

\section{PLEASE CITE THE PUBLISHED VERSION}

http://dx.doi.org/10.1063/1.2034121

\section{PUBLISHER}

(C) American Institute of Physics

\section{VERSION}

VoR (Version of Record)

\section{PUBLISHER STATEMENT}

This work is made available according to the conditions of the Creative Commons Attribution-NonCommercialNoDerivatives 4.0 International (CC BY-NC-ND 4.0) licence. Full details of this licence are available at: https://creativecommons.org/licenses/by-nc-nd/4.0/

\section{LICENCE}

CC BY-NC-ND 4.0

\section{REPOSITORY RECORD}

Yan, Haixue, Hongtao Zhang, Michael J. Reece, and Xianlin Dong. 2015. "Thermal Depoling of High Curie Point Aurivillius Phase Ferroelectric Ceramics”. figshare. https://hdl.handle.net/2134/17767. 


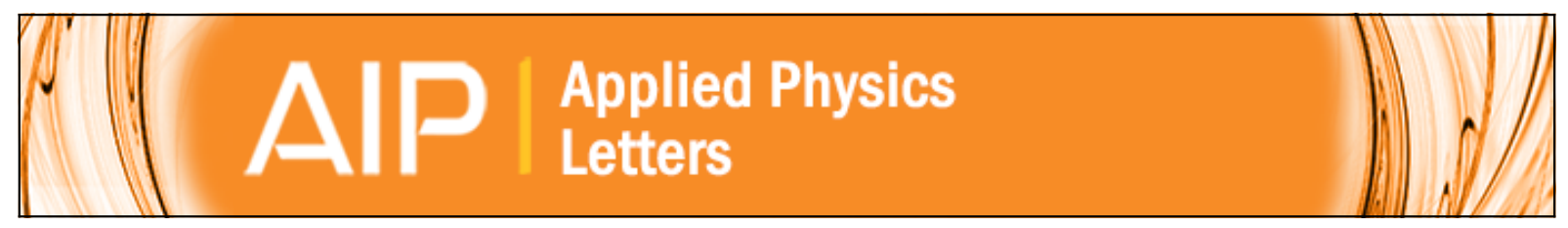

Thermal depoling of high Curie point Aurivillius phase ferroelectric ceramics

Haixue Yan, Hongtao Zhang, Michael J. Reece, and Xianlin Dong

Citation: Applied Physics Letters 87, 082911 (2005); doi: 10.1063/1.2034121

View online: http://dx.doi.org/10.1063/1.2034121

View Table of Contents: http://scitation.aip.org/content/aip/journal/apl/87/8?ver=pdfcov

Published by the AIP Publishing

\section{Articles you may be interested in}

A ferroelectric polarization contribution from defect dipoles in acceptor Aurivillius oxide,

(Na,Bi)0.47(Li,Ce)0.03Bi2Ta1.97Sc0.0308.97

Appl. Phys. Lett. 103, 192908 (2013); 10.1063/1.4829267

Optical anisotropy near the relaxor-ferroelectric phase transition in lanthanum lead zirconate titanate J. Appl. Phys. 114, 053515 (2013); 10.1063/1.4817515

Effect of point defects on thermal depoling behavior of bismuth layer-structured ferroelectric ceramics J. Appl. Phys. 108, 096101 (2010); 10.1063/1.3499627

High performance Aurivillius phase sodium-potassium bismuth titanate lead-free piezoelectric ceramics with lithium and cerium modification

Appl. Phys. Lett. 89, 202905 (2006); 10.1063/1.2388253

Dielectric and ferroelectric properties of tetragonal tungsten bronze $\mathrm{Sr} 2-\mathrm{x} \mathrm{Ca}$ x NaNb $5 \mathrm{O} 15$ (x=0.05-0.35) ceramics

Appl. Phys. Lett. 80, 835 (2002); 10.1063/1.1446997

You don't

still use this

cell phone

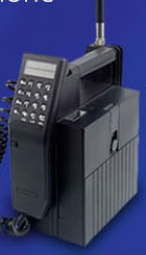

or this computer

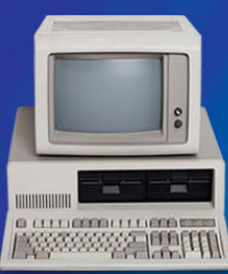

Why are you

still using an

AFM designed in the 80 's?
It is time to upgrade your AFM Minimum $\$ 20,000$ trade-in discount for purchases before August 31st

Asylum Research is today's technology leader in AFM 


\title{
Thermal depoling of high Curie point Aurivillius phase ferroelectric ceramics
}

\author{
Haixue Yan, Hongtao Zhang, and Michael J. Reece ${ }^{\text {a) }}$ \\ Materials Department, Queen Mary University of London, Mile End Road, London, E1 4NS, \\ United Kingdom \\ Xianlin Dong \\ Shanghai Institute of Ceramics, Chinese Academy of Sciences, Dingxi Road, Shanghai, 200050, \\ People's Republic of China
}

(Received 11 April 2005; accepted 7 July 2005; published online 18 August 2005)

\begin{abstract}
The thermal depoling behavior of several different Aurivillius phase ferroelectric ceramics has been studied. This includes two-layer $\left(\mathrm{CaBi}_{2} \mathrm{Nb}_{2} \mathrm{O}_{9}, \mathrm{Ca}_{0.9} \mathrm{Ba}_{0.1} \mathrm{Bi}_{2} \mathrm{Nb}_{2} \mathrm{O}_{9}, \mathrm{Bi}_{3} \mathrm{NbTiO}_{9}, \mathrm{Bi}_{3} \mathrm{Nb}_{1.2} \mathrm{Ti}_{0.8} \mathrm{O}_{9}\right)$, three-layer $\left(\mathrm{Bi}_{4} \mathrm{Ti}_{3} \mathrm{O}_{12}\right)$, and four-layer $\left[\mathrm{CaBi}_{4} \mathrm{Ti}_{4} \mathrm{O}_{15}, \mathrm{Ca}_{0.94}(\mathrm{Na}, \mathrm{Ce})_{0.03} \mathrm{Bi}_{4} \mathrm{Ti}_{4} \mathrm{O}_{15}\right]$ compounds. All of them have a high Curie point $\left(T_{c} \geqslant 675^{\circ} \mathrm{C}\right)$. The orthorhombic structured materials show good resistance to thermal depoling up to temperatures close to their Curie points. However, $\mathrm{Bi}_{4} \mathrm{Ti}_{3} \mathrm{O}_{12}$, which has a monoclinic structure, shows a significant reduction in $d_{33}$ well before its Curie point. The monoclinic distortion produces more non $-180^{\circ}$ ferroelectric domain structures, and it is the thermal instability of these that accounts for their thermal depoling behaviour. Excess $\mathrm{Nb}$ doping of $\mathrm{Bi}_{3} \mathrm{NbTiO}_{9}$ produces a significant reduction in its resistance to thermal depoling, suggesting that the doping produces a lowering of the crystallographic symmetry. (C) 2005 American Institute of Physics. [DOI: 10.1063/1.2034121]
\end{abstract}

Some Aurivillius phase compounds show interesting relaxor $^{1,2}$ and multiferroic ${ }^{3,4}$ properties when $\mathrm{Ba}$ and $\mathrm{Fe}$ are on the $A$ - and $B$-site in the general formula, respectively. In recent years many investigations have concentrated on their potential use in nonvolatile ferroelectric random-access memory (FRAM) (Refs. 5 and 6) and high-temperature piezoelectric applications, ${ }^{7,8}$ because of their fatigue-free properties and high Curie point, respectively.

The general formula of Aurivillius phase materials is $\left(\mathrm{Bi}_{2} \mathrm{O}_{2}\right)^{2+}\left(A_{m-1} B_{m} \mathrm{O}_{3 m+1}\right)^{2-}$, where $A$ is a mono-, di- or trivalent element (or combination) with cuboctahedral coordination. $B$ is a transition element suited to octahedral coordination, and $m$ is the number of octahedral layers in the perovskite slab. The $m$ value can vary from 1 to $6 .^{9}$ It can also be fractional and compounds with $m=1.5,2.5$, and 3.5 are widely known. ${ }^{10}$ It is found that the ferroelectric properties for even $(m=2 n)$ and odd layer $(m=2 n+1)$ Aurivillius phase compounds are different. ${ }^{11}$ The spontaneous polarization $P_{s}$ of even-layer compounds is only along the $a$-axis. Based on their orthorhombic space group $A 2{ }_{1} \mathrm{am}$, the polarization along the $c$-axis is cancelled because of mirror symmetry. However, in odd-layer compound $\mathrm{Bi}_{4} \mathrm{Ti}_{3} \mathrm{O}_{12}(m=3$, monoclinic, space group $P c$ ) a small degree of spontaneous polarization along the $c$-axis can be observed besides the major polarization along the $a$-axis. ${ }^{12-14}$

In Damjanovic's review ${ }^{15}$ of high-temperature piezoelectric materials, Aurivillius phase ferroelectric ceramics were highlighted as important for sensor application. Thermal depoling of ferroelectrics determines the upper temperature limit of their application as piezoelectrics. However, there is very limited information on the thermal depoling of Aurivillius phase materials. In the present work the thermal depoling of Aurivillius phase compounds was studied. For the purpose of high-temperature piezoelectric application, the Curie

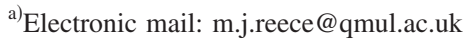

point, $T_{c}$, of the selected compounds is not less than $675^{\circ} \mathrm{C}$. The compounds include even-layer compounds $\mathrm{CaBi}_{2} \mathrm{Nb}_{2} \mathrm{O}_{9}$ $(\mathrm{CBNO}, m=2), \mathrm{Bi}_{3} \mathrm{NbTiO}_{9}(\mathrm{BNTO}, m=2), \mathrm{CaBi}_{4} \mathrm{Ti}_{4} \mathrm{O}_{15}$ $(\mathrm{CBT}, m=4)$ and odd-layer compound $\mathrm{Bi}_{4} \mathrm{Ti}_{3} \mathrm{O}_{12}$ (BIT, $m$ $=3$ ). In order to study the effect of substitution on the thermal depoling, three substituted compounds $\mathrm{Ca}_{0.9} \mathrm{Ba}_{0.1} \mathrm{Bi}_{2} \mathrm{Nb}_{2} \mathrm{O}_{9} \quad(\mathrm{CBBNO}, \quad m=2), \quad \mathrm{Bi}_{3} \mathrm{Nb}_{1.2} \mathrm{Ti}_{0.8} \mathrm{O}_{9}$ (BNTO-D, $m=2$ ) and $\mathrm{Ca}_{0.94}(\mathrm{Na}, \mathrm{Ce})_{0.03} \mathrm{Bi}_{4} \mathrm{Ti}_{4} \mathrm{O}_{15}$ (CNBT, $m=4)$ were also prepared.

Polycrystalline ceramic samples were prepared by conventional ceramic processing. The starting raw materials were $\mathrm{Bi}_{2} \mathrm{O}_{3}$ of $99.975 \%$ purity, $\mathrm{CaCO}_{3}$ of $99 \%$ purity, $\mathrm{BaCO}_{3}$ of $99 \%$ purity, $\mathrm{Na}_{2} \mathrm{CO}_{3}$ of $99.5 \%$ purity, $\mathrm{CeO}_{2}$ of $99.9 \%$ purity, $\mathrm{TiO}_{2}$ of $99.6 \%$ purity, and $\mathrm{Nb}_{2} \mathrm{O}_{5}$ of $99.9 \%$ purity. The materials were mixed by ball milling in ethanol, dried and sieved to under $250 \mu \mathrm{m}$. The calcination conditions were $950{ }^{\circ} \mathrm{C} 2 \mathrm{~h}$ for $\mathrm{CBNO}$ and $\mathrm{CBBNO}, 900{ }^{\circ} \mathrm{C} 4 \mathrm{~h}$ for BNTO and BNTO-D, $850{ }^{\circ} \mathrm{C} 4 \mathrm{~h}$ for BIT and $900{ }^{\circ} \mathrm{C}$ $2 \mathrm{~h}$ for $\mathrm{CBT}$ and CNBT. After calcination, the powders were remilled, dried and sieved to under $500 \mu \mathrm{m}$, and then finally pressed into disks of $10 \mathrm{~mm}$ diameter in a steel die at a pressure of about $200 \mathrm{MPa}$. The pressed specimens were sintered for $1 \mathrm{~h}$ at $1150{ }^{\circ} \mathrm{C}$ for $\mathrm{CBNO}, 1050{ }^{\circ} \mathrm{C}$ for $\mathrm{CBBNO}$, $1080{ }^{\circ} \mathrm{C}$ for BNTO and BNTO-D, $1150{ }^{\circ} \mathrm{C}$ for BIT, $1175^{\circ} \mathrm{C}$ for $\mathrm{CBT}$, and $1150{ }^{\circ} \mathrm{C}$ for $\mathrm{CNBT}$ in air. Electrodes for high-temperature electrical property measurements were fabricated with fired-on platinum paste (Gwent Electronic Materials Ltd., C2011004D5).

X-ray diffraction (XRD) patterns for the sintered ceramics were obtained with an X-ray diffractometer (Siemens D5000) using $\mathrm{Cu} K \alpha$ radiation. The samples, except BIT, for piezoelectric measurements were poled by applying a dc electric field of $8-15 \mathrm{kV} / \mathrm{mm}$ for $5-15 \mathrm{~min}$ in silicone oil at $200{ }^{\circ} \mathrm{C}$. The maximum poling field that could be achieved for BIT was below $1 \mathrm{kV} / \mathrm{mm}$ because of its high conductivity. ${ }^{16}$ The piezoelectric constant, $d_{33}$, was measured 


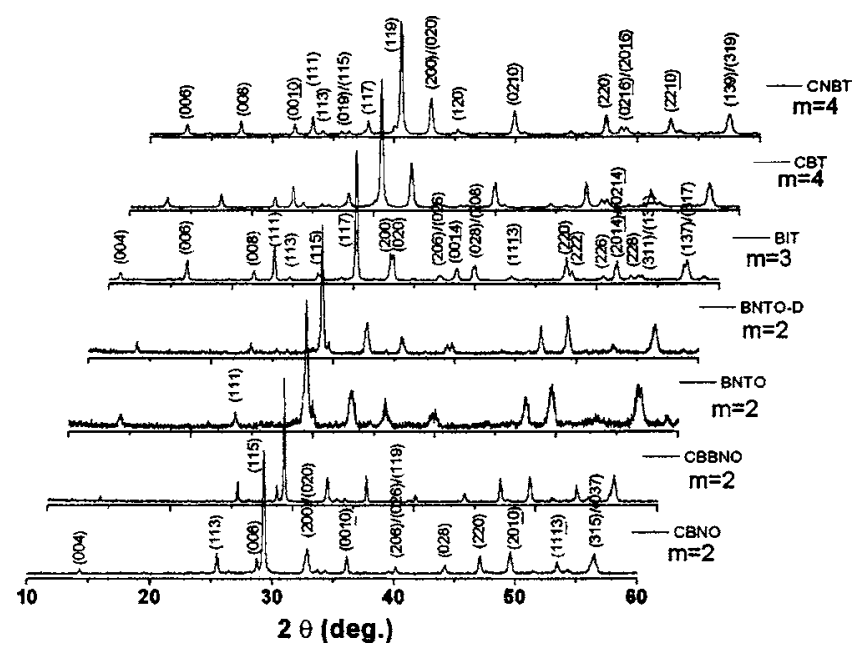

FIG. 1. XRD patterns of sintered ceramic powders.

using a piezo $d_{33}$ meter (ZJ-3B, Institute of Acoustics, Academia Sinica). The temperature dependence of dielectric constant and loss were measured at $1 \mathrm{MHz}$ using a LCR meter (Agilent 4284A) connected to a furnace. Thermal depoling experiments were conducted by holding the poled samples for $2 \mathrm{~h}$ at high temperatures, cooling to room temperature, measuring $d_{33}$, and repeating the procedure at intervals of $100{ }^{\circ} \mathrm{C}$ up to a temperature above $T_{c}$.

Figure 1 shows the XRD patterns of sintered ceramic powders of these compounds. The materials are all singlephase within the sensitivity of the technique based on related crystal structure parameters, ${ }^{17-19}$ except BNTO and BNTO-D. In the XRD patterns for BNTO most of the diffraction peaks match the main phase of the BNTO structure with the exception of a small peak at about $2 \theta=30^{\circ}$, which matches the strongest peak (117) for BIT. The doped BNTO-D ceramics also contain BIT phase. The amount of second phase in BNTO is higher than that in BNTO-D. The strongest diffraction peak for two layer compounds CBNO, CBBNO, BNTO, and BNTO-D is (115), for three layer BIT it is (117) and for four layer CBT and CNBT it is (119), which is consistent with the strongest diffraction peak $\left(\begin{array}{lll}1 & 1 & 2 m+1)\end{array}\right)$ of Aurivillius phases generally. ${ }^{20}$

Figure 2 shows the temperature dependence of the di-

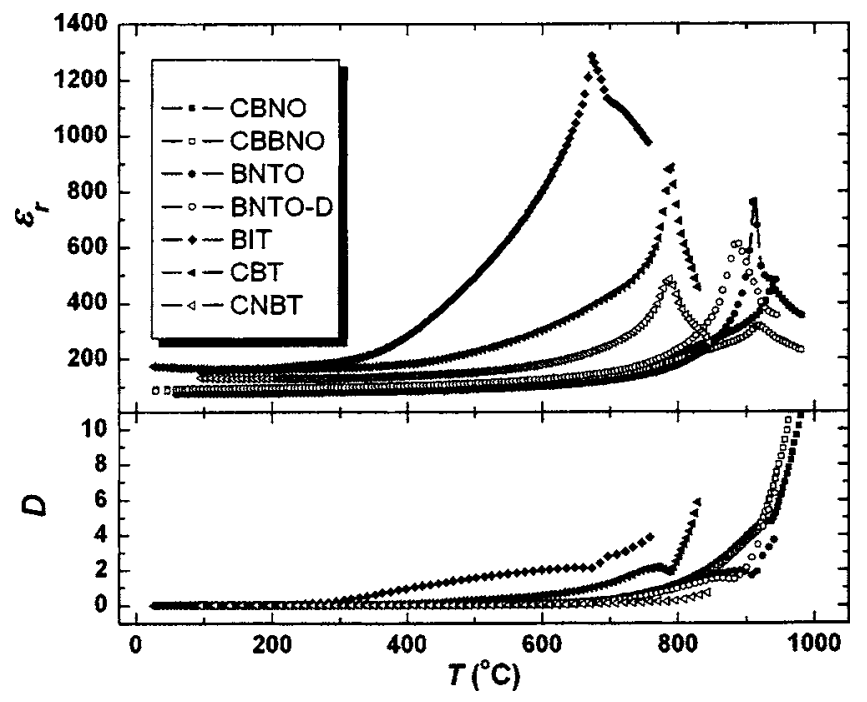

FIG. 2. Temperature dependence of dielectric constant and loss at $1 \mathrm{MHz}$.

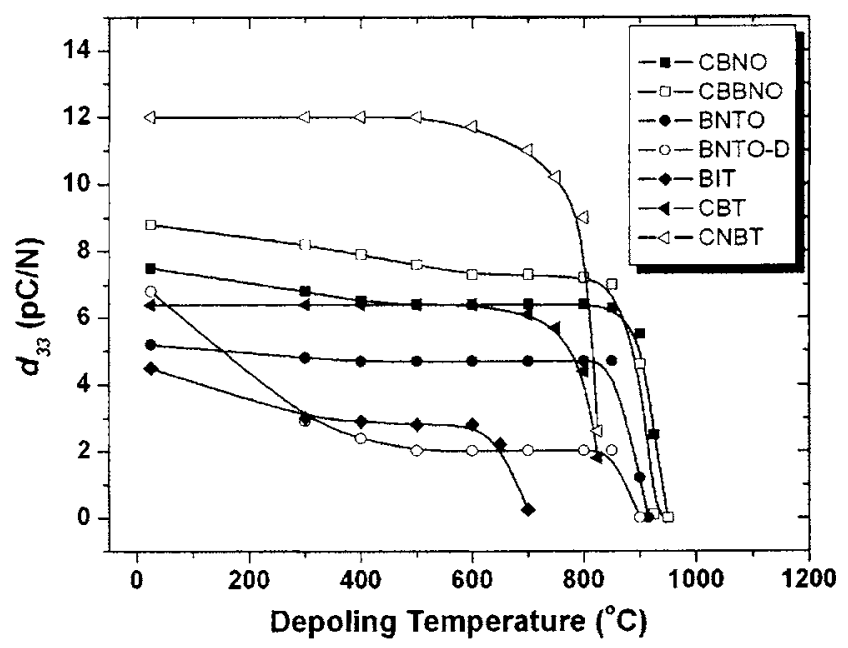

(a)

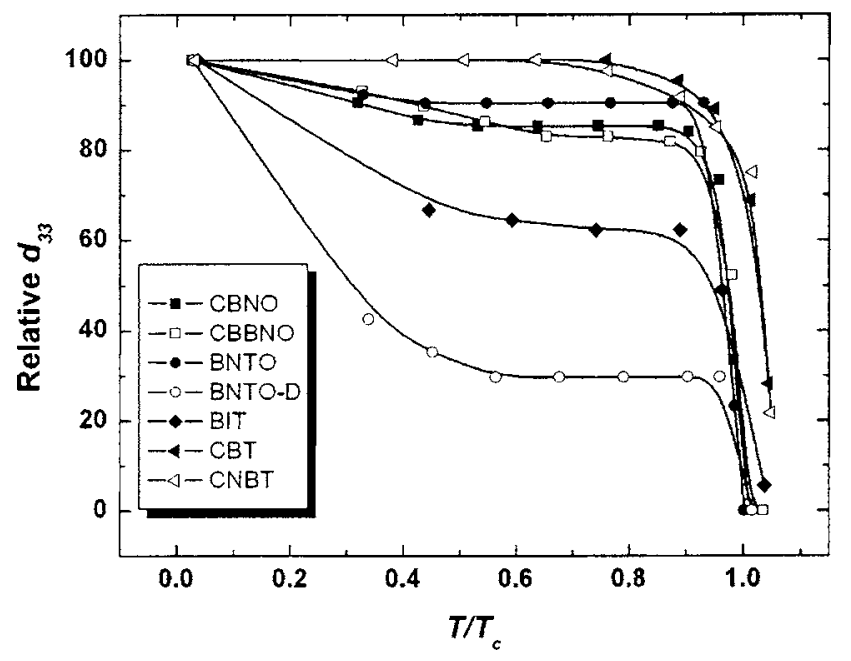

(b)

FIG. 3. Effect of thermal depoling on piezoelectric properties: (a) the change of $d_{33}$ after annealing for $2 \mathrm{~h}$; (b) the same data plotted as relative $d_{33}$ and homologous temperature.

electric permittivity and loss of the compounds at $1 \mathrm{MHz}$. The Curie point is $940{ }^{\circ} \mathrm{C}, 918^{\circ} \mathrm{C}, 913{ }^{\circ} \mathrm{C}, 886^{\circ} \mathrm{C}$, $675^{\circ} \mathrm{C}, 790^{\circ} \mathrm{C}$, and $787^{\circ} \mathrm{C}$ within an error of $\pm 2{ }^{\circ} \mathrm{C}$ for CBNO, CBBNO, BNTO, BNTO-D, BIT, CBT, and CNBT, respectively. There is a loss peak at a few degrees below the Curie points. A possible explanation for this peak is that it is associated with the movement of ferroelectric domain walls. Displacement of domain walls contributes to the dielectric and mechanical losses of ferroelectric materials and, particularly near the phase transition temperature, may dominate other loss mechanisms. ${ }^{21}$ The room temperature $d_{33}$ values of the Aurivillius phase compounds are relatively low (Fig. 3) compared with those of PZT (lead zirconate titanate, $200-600 \mathrm{pC} / \mathrm{N})$. This is because of their high coercive fields and the two-dimensional orientation restriction of the switching of the $P_{s}$ between the $a-b$ axes. ${ }^{22}$ After substitution, the room temperature $d_{33}$ value of CBBNO, BNTO-D, and CNBT is higher than that of CBNO, BNTO and CBT, respectively.

In ferroelectric materials, domain wall movement can produce a significant contribution to the piezoelectric properties. ${ }^{23,24}$ In Aurivillius phase materials, even-layer materials, such as $\mathrm{SrBi}_{4} \mathrm{Ti}_{4} \mathrm{O}_{15}(m=4)$, show relatively little pi- 
ezoelectric hysteresis. ${ }^{25,26}$ A possible reason for this is the absence of a contribution from piezoelectrically active non$180^{\circ}$ domain walls. This is not the case for the odd-layer BIT $(m=3)$, which has several types of non- $180^{\circ}$ domain walls. ${ }^{25-27}$ However, a nearly hysteresis-free and constant $d_{33}$ as a function of the frequency and applied ac pressure was found for $\mathrm{Nb}$ doped BIT at room temperature. ${ }^{26}$ A possible reason for this is that the $\mathrm{Nb}$ doping suppresses the monoclinic distortion in BIT so that the structure is similar to that of the orthorhombic $\mathrm{SrBi}_{4} \mathrm{Ti}_{4} \mathrm{O}_{15}(m=4){ }^{26}$

Figure 3 shows the effect of thermal depoling on the piezoelectric properties. The $d_{33}$ values were measured at room temperature after annealing for $2 \mathrm{~h}$ at the $x$-axis temperature. When the annealing temperature is near $T_{c}$, the $d_{33}$ values of all the compounds decrease rapidly, and tend to zero when the temperature is increased above $T_{c}$. The thermal depoling behavior of the materials differs when the annealing temperature is below $0.6 T / T_{c}$. There is about $40 \%$ drop in $d_{33}$ for BIT below $0.6 T / T_{c}$. While Messing et al. ${ }^{28}$ reported that for $\mathrm{Nb}$ doped $\mathrm{BIT} \mathrm{Bi}_{4} \mathrm{Ti}_{3-x / 5} \mathrm{Nb}_{x / 5} \mathrm{O}_{12}(x=0.2)$ there was no obvious drop of $d_{33}$ below $500{ }^{\circ} \mathrm{C}$. The monoclinic distortion of BIT produces more types of non- $180^{\circ}$ domain wall. These observations suggest that these non- $180^{\circ}$ domain walls are thermally unstable well below the Curie point, and give rise to the observed degradation of $d_{33}$. The obvious depoling of BNTO-D below $0.6 T / T_{c}$ could also be attributed to a possible, but as of yet unconfirmed, monoclinic distortion caused by excess $\mathrm{Nb}$ doping in BNTO. There is a small decrease of $d_{33}$ for CBNO, CBBNO, and BNTO below $0.6 T / T_{c}$. While for the four-layer CBT and CNBT the $d_{33}$ does not drop until the temperature is greater than $0.6 T / T_{c}$. Based on the similar depoling behaviors of two-layer CBNO, CBBNO and four-layer CBT, CNBT, orthorhombic structured materials are more stable to thermal depoling than monoclinic materials.

In summary, it is suggested that some non- $180^{\circ}$ domain walls are thermally unstable below $T_{c}$ and give rise to thermal depoling. In Aurivillius phase materials, monoclinic distortion produces more types of non- $180^{\circ}$ domain walls, which therefore makes the materials less resistant to thermal depoling.
${ }^{1}$ G. A. Smolenskii, V. A. Isupov, and A. I. Agranovskaya, Sov. Phys. Solid State 3, 651 (1961).

${ }^{2}$ J. F. Fernandez, A. C. Caballero, M. Villegas, J. De Frutos, and L. Lascano, Appl. Phys. Lett. 81, 4811 (2002).

${ }^{3}$ L. Fuentes, M. Garcia, J. Matutes-Aquino, and D. Rios-Jara, J. Alloys Compd. 369, 10 (2004).

${ }^{4}$ A. Srinivas, D.-W. Kim, K. S. Hong, and S. V. Suryanarayana, Mater. Res. Bull. 39, 55 (2004).

${ }^{5}$ C. Dearaujo, J. D. Cuchiaro, L. D. McMillan, M. C. Scott, and J. F. Scott, Nature (London) 374, 627 (1995).

${ }^{6}$ B. H. Park, B. S. Kang, S. D. Bu, T. W. Noh, J. Lee, and W. Jo, Nature (London) 401, 682 (1999).

${ }^{7}$ L. Pardo, A. Castro, P. Millan, C. Alemany, R. Jimenez, and B. Jimenez, Acta Mater. 48, 2421 (2000).

${ }^{8}$ S. H. Hong, S. Trolier-Mckinstry, and G. L. Messing, J. Am. Ceram. Soc. 83, 113 (2000).

${ }^{9}$ Y. Wu, M. J. Forbess, S. Seraji, S. J. Limmer, T. P. Chou, C. Nguyen, and G. Cao, J. Appl. Phys. 90, 5296 (2001).

${ }^{10}$ T. Kikuchi, A. Watanabe, and K. Uchida, Mater. Res. Bull. 12, 299 (1977).

${ }^{11}$ R. E. Newnham, R. W. Wolfe, and J. F. Dorrian, Mater. Res. Bull. 6, 1029 (1971).

${ }^{12}$ J. V. Landuty, G. Remaut, and S. Amelinckx, Mater. Res. Bull. 4, 329 (1969).

${ }^{13}$ S. E. Cummins and L. E. Cross, J. Appl. Phys. 39, 2268 (1968).

${ }^{14}$ Y. Shimakawa, Y. Kubo, Y. Tauchi, H. Asano, T. Izumi, and Z. Hoiroi, Appl. Phys. Lett. 79, 2791 (2001).

${ }^{15}$ D. Damjanovic, Curr. Opin. Solid State Mater. Sci. 3, 469 (1998).

${ }^{16}$ H. S. Shulman, M. Testorf, D. Damjanovie, and N. Setter, J. Am. Ceram. Soc. 79, 3124 (1996).

${ }^{17}$ XRD PDF Number 49-608.

${ }^{18}$ XRD PDF Number 80-2143.

${ }^{19}$ H. Yan, C. Li, J. Zhou, W. Zhu, L. He, and Y. Song, Jpn. J. Appl. Phys., Part 1 39, 6339 (2000).

${ }^{20}$ X. F. Du and I. W. Chen, J. Am. Ceram. Soc. 81, 3253 (1998).

${ }^{21}$ D. Damjanovic, Rep. Prog. Phys. 61, 1267 (1998).

${ }^{22}$ T. Takenaka and K. Sakata, J. Appl. Phys. 55, 1092 (1984).

${ }^{23}$ Q. M. Zhang, W. Y. Pan, S. J. Jang, and L. E. Cross, J. Appl. Phys. 64, 6445 (1988).

${ }^{24}$ Q. M. Zhang, H. Wang, N. Kim, and L. E. Cross, J. Appl. Phys. 75, 454 (1994).

${ }^{25}$ I. M. Reaney and D. Damjanovic, J. Appl. Phys. 80, 4223 (1996).

${ }^{26}$ D. Damjanovic, M. Demartin, H. S. Shulman, M. Testorf, and N. Setter, Sens. Actuators, A 53, 353 (1996).

${ }^{27}$ L. Sagalowicz, F. Chu, P. D. Martin, and D. Damjanovic, J. Appl. Phys. 88, 7258 (2000).

${ }^{28}$ S. H. Hong, S. Trolier-Mckinstry, and G. L. Messing, J. Am. Ceram. Soc. 83, 113 (2000). 